\title{
PENCEGAHAN MONEY POLITIC DALAM PEMILIHAN UMUM MELALUI PENGUATAN KEBIJAKAN NON PENAL
}

\author{
Leni Anggraeni \\ Departemen Pendidikan Kewarganegaraan, Universitas Pendidikan Indonesia \\ Email : l_anggraeni@upi.edu \\ Hilal Ramdhani \\ Departemen Pendidikan Kewarganegaraan, Universitas Pendidikan Indonesia \\ Email: hilal.ramdhani18@gmail.com
}

\begin{abstract}
ABSTRAK
Money politic merupakan tindakan melanggar hukum, serta akan berdampak negatif bagi keberlangsungan demokrasi di Indonesia. Saat ini penegakan hukum money politic sangat rendah, dikarenakan pengawasan yang kurang, perilaku masyarakat yang mendukung serta sistem pemilihan umum proporsional terbuka membuat tindakan money politic semakin berkembang di Indonesia. Penelitian ini menggunakan pendekatan hukum-normatif yang bertujuan mengetahui pada aspek sejarah serta konsep tindakan money politic. Hasil yang diperoleh menunjukan bahwa dengan semakin berkembangnya tindakan money politic membuat kondisi demokrasi tidak sesuai dengan tujuan idealnya, sehingga perlu adanya pendekatan non penal yang bersifat pencegahan dalam menghilangkan tindakan money politic.
\end{abstract}

Kata kunci : Money Politic, Pemilihan Umum, Kebijakan Non Penal.

\section{ABSTRACT}

Money politic is an act against law and it will be disadvantage in democracy in Indonesia. For this time, law enforcement against money politic is very low, because of less in controlling, and also because of social behavior that supports proportional open election system that make money politic in Indonesia develops more. This research uses normative law approach that has purpose to know about money politic act's concept and its historical aspect. The result from this research shows that increasing of money politic can make democratic condition will be not suitable with ideal purpose, so it needs non-penal approaches that for preventing in eliminating money politic act.

Keywords : Money Politic, Electoral Vote, Non Penal Policy 


\section{Pendahuluan}

Pemilihan umum merupakan suatu cara untuk dapat memilih pemimpin baik pada ranah legislatif maupun eksekutif di Indonesia, selain itu pemilihan umum merupakan pembatasan kekuasaan pemimpin negara dalam menjalankan kekuasaannya, sehingga pemilihan umum merupakan kegiatan yang sangat penting bagi pembangunan nasional.

Konstelasi politik selalu memunculkan dinamika, terutama pada saat kampanye pemilihan umum (Harry, 2013). Dinamika politik dapat bersifat positif maupun negatif, salah satu aspek negatif yaitu adanya money politic yang saat ini sudah menjadi rahasia umum di masyarakat. Hal tersebut dikarenakan uang sangat mempesona bagi masyarakat terkait dengan perebutan kekuasaan. Aura uang sangat hebat untuk menarik simpati masyarakat yang secara politik memiliki keterbatasan dalam memahami hakekat politik jangka panjang (Salam dalam Fatkhurohman, (2010;32).

Pada tataran hukum formil di Indonesia, money politic merupakan suatu tindakan yang melawan hukum. Hal itu dibuktikan dalam Pasal 73 ayat (4) UndangUndang Republik Indonesia Nomor 3 tahun 1999 tentang Partai Politik yang berbunyi barang siapa waktu diselenggarakannya pemilu menurut undang-undang ini dengan pemberian atau janji, menyuap seseorang, baik supaya itu tidak menjalankan haknya untuk memilih maupun supaya ia menjalankan haknya dengan cara tertentu, dipidana dengan hukuman penjara paling lama 3 (tiga) tahun. Pidana itu dikenakan juga kepada pemilih yang menerima suap berupa pemberian atau janji berbuat sesuatu (Azwar, 2016;234). Aturan hukum tersebut menandakan bahwa perlu adanya penindakan dari aparatur penegak hukum untuk memberikan hukuman terhadap pelaku money politic.

Pada tataran penerapan aturan hukum mengenai tindakan money politic selalu mendapatkan rintangan dalam penegakannya, dikarenakan masyarakat sudah menganggap tindakan money politic adalah tindakan yang wajar dilakukan dalam pemilihan umum, selain pengawasan yang lemah terhadap tindakan money politic membuat tindakan tersebut selalu terjadi dalam setiap pemilihan umum. 
Permasalahan penegakan hukum terhadap tindakan money politic menandakan adanya kekurangan dari penegakan hukum pidana, sehingga perlu adanya pendekatan hukum yang bersifat preventif yang bertujuan untuk memperbaiki kondisi-kondisi sosial budaya tertentu, namun secara tidak langsung mempunyai pengaruh preventif terhadap kejahatan (Firmansyah, 2012;389). Hal tersebut menandakan bahwa untuk menghilangkan tindakan money politic seharusnya kebijakan non penal lebih diutamakan daripada kebijakan penal yang bersifat represif.

\section{Metode Penelitian}

Penelitian ini menggunakan jenis penelitian dalam bidang hukum, yaitu menggunakan metode yuridis-normatif. Dalam penelitian hukum yang bersifat yuridisnormatif, bahan pustaka merupakan sumber bahan hukum utama dan dasar yang dalam penelitian hukum termasuk kedalam data sekunder, sehingga jenis data yang dicari adalah data sekunder. Karena sifat dari kegiatan penelitian ilmiah yang dilakukan adalah berupa penelitian normatif, maka metode kepustakaanlah yang paling sesuai dengan sifat penelitian hukum ini (Ramdhani, 2017;25). Jenis pendekatan yang digunakan dalam penelitian ini adalah pendekatan sejarah, dan pendekatan konsep (Putera, 2017;35). Kedua pendekatan itu dilakukan untuk mengetahui money politic pada aspek sejarah yang mengakibatkan persepsi masyarakat terhadap money politic sebagai tindakan yang lumrah, serta mengetahui konsep yang menjelaskan kebijakan non penal dalam mencegah money politic.

\section{Pembahasan \\ Realitas Money Politic dalam Pemilihan Umum}

Pemilihan umum di Indonesia merupakan bagian yang sangat penting dalam menguatkan prinsip demokrasi. Akan tetapi, dalam penerapan pemilihan umum muncul tindakan-tindakan yang tidak sesuai dengan etika politik dan hukum formil, salah satunya yaitu money politic. Praktek money politics merupakan penguatan melanggar hukum karena termasuk dalam perbuatan tindak pidana, tetapi masyarakat tidak memperdulikan bahkan bersedia menerima segala macam materi yang diberikan oleh pihak yang mencalonkan diri (Ratnasari dan 
Adi, 2016;1867). Realita tersebut berakibat negatif bagi penegakan hukum di Indonesia, karena secara fisolofis hukum merupakan penjelmaan dari kehendak rakyat, akan tetapi jika kehendak rakyat bertentangan dengan moral dan etika hukum, maka terjadi suatu dilema dalam kehidupan bernegara.

Tindakan money politic banyak terjadi dipedesaan, hal tersebut dikarenakan pengawasan yang kurang dari aparatur penegak hukum, keasadaran politik yang kurang serta tingkat ekonomi yang rendah membuat masyarakat desa sangat mudah menjadi sasaran dari tindakan money politic. Bentuk praktik politik uang yang terjadi didaerah pedesaan berupa pemberian sembako, pembagian uang dalam forum pengajian, serta dana bantuan desa. Praktik ini dilakukan untuk memengaruhi pemilih agar memilih calon tertentu pada hari pencoblosan (Fatkhurohman, 2010;33). Hal ini menandakan bahwa penegakan hukum tindakan money politic dipedesaan sangat rendah.

Tindakan money politic yang terjadi saat ini, bukan hanya dipedesaan bahkan terjadi pula di perkotaan, walau secara kuantitas tidak lebih banyak terjadi di pedesaan. Hal tersebut dikarenakan manusia modern yang berada diperkotaan telah menjadikan uang sebagai tujuan utama, padahal sebetulnya uang hanya merupakan sarana (Rahmatiah, 2015;377). Orientasi tersebut mengakibatkan money politic menjadi sarana yang digunakan untuk dapat menarik dukungan dari masyarakat perkotaan.

Realitas money politics membuat keresahan bagi kemajuan berbangsa dan bernegara di Indonesia, karena adanya money politics yang mempengaruhi perilaku memilih, mencederai terwujudnya pemilu yang demokratis (Solihah, 2016;107). Ketika tindakan ini semakin berkembang dalam kehidupan bernegara di Indonesia, maka akan memunculkan tindakan-tindakan korupsi yang dilakukan oleh pemimpin negara.

Bila politik uang ikut dikelompokkan dalam bentuk yang tidak riil, maka keseluruhan pemilih yang menginginkan politik uang menjadi sebanyak 39,6 persen. Jumlah itu merupakan gabungan dengan 10,6 persen yang menginginkan pembagian sembako, 8,8 persen yang meminta perbaikan jalan, dan 5,3 persen untuk memberi modal usaha (Sumarto dalam Fatkhurohman, 2010;31). 
Realitas masyarakat yang membutuhkan politik uang juga menjadi suatu hal yang sangat membahayakan bagi keberlangsungan demokrasi yang jujur di Indonesia.

\section{Karakteristik Money Politic}

Money politic harus mengandung unsur-unsur berikut. Pertama, harus sengaja memberi uang atau materi lainnya kepada pemilih. Kedua, sengaja menjanjikan uang atau materi lainnya kepada pemilih. Kedua unsur tersebut dilakukan dengan tujuan agar penerima uang atau meteri lainnya itu untuk memilih calon tertentu. Atau menggunakan hak pilihnya dengan cara tertentu sehingga surat suaranya menjadi tidak sah (Hadi dalam Azwar, 2016;234). Hal tersebut menandakan bahwa adanya unsur kesengajaan dalam tindakan politik uang yang ditujukan untuk memilih calon tertentu atau bahkan ditujukan agar masyarakat tidak memilih dalam pemilihan umum.

Dalam hukum pidana Indonesia membuktikan suatu kesengajaan perlu adanya bukti yang meyakinkan terhadap tindakan yang dilakukan oleh seseorang atau sekelompok orang, akan tetapi dalam tindakan money politic sangat sulit mencari bukti adanya kesengajaan politik uang, karena masyarakat mendukung bahkan membutuhkan uang atau materi lainnya yang diberikan oleh seseorang atau sekelompok orang dalam pemilihan umum.

Money politic erat kaitannya dengan politik, jabatan, dan kekuasaan (Azwar, 2016;247). Ketiga unsur tersebut sangat berperan penting dalam pemilihan umum, sehingga mengakibatkan money politic merupakan suatu keniscayaan, padahal kehidupan politik sejatinya adalah untuk mewujudkan idealisme bagi masyarakat dan negara (Azwar, 2016;240).

Politik uang juga sangat rentan pada saat penyelenggaraan pemilu termasuk pada pemilu legislatif (Rahmatiah, 2015;375). Secara wilayah pemilu legislatif terjadi diseluruh wilayah Indonesia, maka kecenderungan politik uang sangat banyak disetiap daerah diIndonesia. Hal tersebut menandakan bahwa sulit untuk memberikan kategori sesuai karakteristik money politic dalam setiap pemilihan umum, karena pengawasan terhadap kegiatan kampanye politik didaerah pedalaman sangat kurang. 


\section{Memahami Makna Kebijakan Non Penal}

Kebijakan

dalam

menanggulangi setiap kejahatan yang terdapat dimasyarakat termasuk dalam kebijakan kriminal. Muhammad (2009;234) kebijakan kriminal yaitu upaya penanggulangan kejahatan dengan pendekatan:

a. Ada keterpaduan (integralitas) antara politik kriminal dan politik sosial.

b. Ada keterpaduan (integralitas) antara upaya penanggulangan kejahatan dengan jalur "penal" dan "non-penal".

Pentingnya keterpaduan antara politik kriminal dan politik sosial menjadi unsur yang sangat penting untuk menghilangkan politik uang di Indonesia, selain itu adanya keterpaduan antara kebijakan non penal maupun kebijakan penal dalam menaggulangi kejahatan merupakan aspek yang sangat penting untuk mengoptimalkan pencegahan politik uang.

Pendekatan

dalam

menghilangkan suatu kejahatan termasuk money politic terbagi menjadi dua, yaitu lewat jalur penal (hukum pidana) dan lewat jalur non penal (bukan/diluar hukum pidana). Upaya penyelesaian melalui jalur penal lebih menitikberatkan pada sifat represif (pemberantasan), sedangkan jalur non penal kebijakan ini lebih menitikberatkan pada sifat preventif penangkalan) (Arif dalam Muhammad, 2009;234-235). Kedua jalur tersebut mempunyai perbedaan yang sangat kontras dan mempunyai tujuan yang berbeda. Dalam upaya menghilangkan kejahatan sebenarnya tidak bisa hanya mengandalkan salah satu jalur (penal/nonpenal) akan tetapi kedua jalur tersebut harus saling bersinergi.

Aspek pemberian hukuman antara kebijakan penal dan non penal sangat berbeda. Anjari $(2015 ; 107)$ sarana penal dilakukan dengan menjatuhkan pidana yang bersifat pembalasan, dan tindakan yang bersifat pembimbingan (treatment) serta pemulihan (restore). Sedangkan sarana non penal dilakukan dengan mengedepankan pendekatan sosial kemasyarakatan sebagai upaya preventif mencegah terjadinya tindak pidana. Hal tersebut menandakan bahwa pendekatan penal dilakukan ketika seseorang atau sekelompok orang sudah terbukti secara sah lewat pengadilan melakukan perbuatan yang melanggar hukum, sedangkan 
pendekatan non penal dilakukan diluar jalur hukum, sehingga penerapannya melalui kemasyarakatan dan bersifat preventif.

Praktik penegakan hukum di Indonesia tidak selamanya mengandalkan pendekatan penal, karena tidak semua permasalahan yang terjadi dimasyarakat dapat diselesaikan melalui jalur hukum, bahkan beberapa tindakan yang secara hukum dianggap melanggar, justru masyarakat menganggapnya tindakan yang wajar, seperti money politic.

\section{Penerapan Kebijakan Non Penal pada tindakan Money Politic}

Money poilitic adalah salah satu dari sekian banyak permasalahan yang muncul terkait pemilihan umum. Lemahnya pengawasan dan ketegasan hukum menyebabkan money politic sangat mudah terjadi (Azwar, 2016;233). Hal tersebut menandakan bahwa salah satu permasalahan adanya tindakan money politic adalah pengawasan yang kurang dan ketegasan dari aparatur penegak hukum. Ketika tindakan tersebut kurang diawasi, maka sulit untuk membawa tindakan tersebut ke pengadilan untuk diselesaikan melalui jalur penal.
Pada unsur lain, yaitu masyarakat sebagai unsur yang sangat penting dalam mengontrol kehidupan sosial justru ikut dalam tindakan money politic. Solihah $(2016 ; 105)$ pada proses demokrasi di Indonesia, praktek money politic tumbuh subur, karena dianggap sebagai suatu kewajaran masyarakat tidak peka terhadap bahayanya. Perilaku masyarakat yang tidak mencerminkan dukungan terhadap penindakan hukum menjadi hambatan yang besar untuk membuat demokrasi yang ideal.

Pada aspek sistem demokrasi di Indonesia juga kurang mendukung dalam pencegahan money politic, sebab sistem proporsional terbuka mendorong, mau tidak mau, money politic (politik uang) dan kecurangankecurangan dalam bentuk lainnya (Halim, 2014;2). Sistem proporsional ini mendorong setiap calon untuk melakukan kampanye, bahkan melawan kader dari partainya sendiri, sehingga tindakan-tindakan yang tidak sesuai dengan hukum formil di Indonesia sangat rentan terjadi.

Permasalahan yang terjad saat ini yang diakibatkan oleh money politik yaitu membuat politik menjadi bias, penyalahgunaan

JURUSAN ILMU HUKUM, FHIS UNDIKSHA 
uang, pemilu sulit menampakan ciri kejujuran, keadilan serta persaingan yang adil. Pemilu seperti ini akhirnya menciptakan pemerintah yang tidak memikirkan nasib dan kesejahteraan rakyat (Suprianto, Arsyad dan Tawulo, 2016;3). Sehingga masyarakat yang akan menjadi korban, karena kepentingan dalam jangka panjang dikorbankan dalam praktik money politic yang hanya berorientasi pada materi jangka pendek.

Permasalahan mengenai money politic yang terjadi saat ini menandakan perlu adanya pendekatan yang bertujuan untuk menghilangkan tindakan money politic melalui jalur non penal. Hal tersebut dikarenakan, keterbatasan upaya penal yang kurang efektif dalam aspek pencegahan, maka perlu adanya penanggulangan kejahatan yang tidak hanya bersifat penal, akan tetapi juga dapat menggunakan sarana-sarana atau kebijakan yang bersifat non penal (Firmansyah, 2011;389).

Secara praktik maka perlu adanya pendekatan non penal yang dilakukan oleh elemen-elemen di masyarakat, terutama pentingnya unsur kesadaran masyarakat. Dalam penelitian ini perlu adanya beberapa tindakan yang harus dilakukan oleh partai politik, $\begin{array}{lrr}\text { masyarakat dan } & \text { lembaga } \\ \text { pendidikan dalam } & \text { mencegah } \\ \text { tindakan money politik. } & \end{array}$

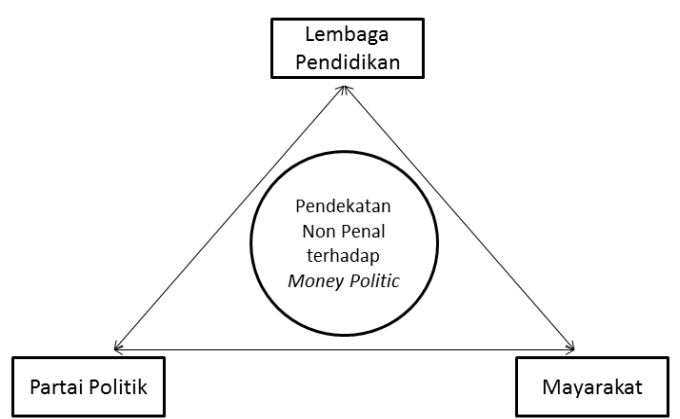

Gambar 1. Pendekatan Non Penal dalam Tindakan Money Politic

Gambar tersebut menjelaskan bahwa dalam mengoptimalkan pendekatan non penal perlu adanya dukungan dari lembaga pendidikan baik formal, informal dan non formal, karena dengan cara tersebut masyarakat Indonesia akan mengetahui tindakan yang melanggar hukum atau sesuai dengan hukum. Selain itu perlu adanya dukungan yang masih dari masyarakat untuk senantiasa fokus pada jangka panjang, bukan pada jangka pendek, sehingga masyarakat akan sadar betapa pentingnya pemilihan umum bagi keberlangsungan bernegara.

Aspek yang sangat mendukung juga dari partai politik Kholmi (2013;364). Partai politik berfungsi 
sebagai suatu organisasi yang berkompetisi membentuk pemerintahan Indonesia. Hal tersebut menandakan bahwa pentingnya partai politik dalam membentuk pemerintahan, maka perlu adanya kegiatan dari partai politik untuk dapat memberikan pendidikan politik kepada kader partai.

\section{Simpulan}

Pemilihan umum erat kaitannya dengan tindakan money politic yang dakibatkan pengawas yang lemah dari penegak hukum, keadaan masyarakat yang menganggap bahwa tindakan money politic adalah suatu hal yang wajar, serta sistem pemilihan umum yang proporsional terbuka membuat tindakan money politic semakin berkembang di Indonesia. Dalam menanggulangi tindakan money politic tidak bisa hanya mengandalkan pendekatan penal yang bersifat represif, perlu adanya penguatan terhadap pendekatan non penal yang bersifat preventif, sehingga masyarakat akan sadar dan peduli mengenai pentingnya hidup berdemokrasi tanpa adanya tindakan money politic yang melanggar hukum formil di Indonesia.

\section{Daftar Pustaka}

Azwar, A. (2016). Kiai, Money Politic dan Pragmatisme Politik dalam Perspektif Siyasah Syar'iyyah: Studi Kasus Pilkades Plosorejo Tahun 2013. Jurnal Agama dan Hak Azazi Manusia, 5(2), hlm. 226-255.

Anjari, W. (2015). Penjatuhan Pidana Mati di Indonesia dalam Perspektif Hak Asasi Manusia. E-Journal WIDYA Yustisia, 1(2), hlm. 107-115.

Fatkhurohman. (2010). Pilkada dan Masa Depan Penguatan Demokrasi di Daerah. Jurnal Konstitusi, 3(2), hlm. 29-50.

Firmansyah, H. (2011). Upaya Penanggulangan Tindak Pidana Terorisme di Indonesia. Jurnal Mimbar Hukum, 23(2), hlm. 376-393.

Halim, A. (2014). Dampak Sistem Proporsional Terbuka terhadap Perilaku Politik (Studi Kasus Masyarakat Sumenep Madura Dalam Pemilihan Legislatif 2014). Jurnal Humanity, 9(2), hlm. 111.

Harry S, E. (2013). Dinamika Komunikasi Politik dalam Pemilihan Umum. LP3 Fikom Unpad, 1, 163-172. 
https://doi.org/10.24198/jkk. vol1n2.6

Kholmi, M. (2013). Persepsi Pengurus Partai terhadap Akuntabilitas Keuangan Partai Politik. Jurnal Reviu Akuntansi dan Keuangan, 3(1), hlm. 363371

Muhammad. (2009). Aspek Perlindungan Anak dalam Tindak Kekerasan (Bullying) terhadap Siswa Korban Kekerasan di Sekolah (Studi Kasus di SMK Kabupaten Banyumas). Jurnal Dinamika Hukum, 9(3), hlm. 230-236.

Putera, H.P. (2017). Pelarangan Import Drama Republik Korea oleh Republik Rakyat Tiongkok dalam Perspektif National Interrest dan Hubungan Internasional. Jurnal Komunikasi Hukum, 3(2), hlm. 33-39.

Rahmatiah. (2015). Sikap dan Pengetahuan Mayarakat terhadap Money Politic dalam Pemilu Legislatif Tahun 2014 di Kabupaten Gowa. Jurnal AlDaulah, 4(2), hlm. 375-390.

Ramdhani, H. (2017). Pencegahan White Collar Crime melalui Kebijakan Non Penal. Jurnal Somasi, 1(1),hlm. 19-31.

Ratnasari, D dan Adi, A.S. (2016). Hubungan Penerimaan Money
Politic Dengan Tingkat Partisipasi Politik Dalam Pemilihan Kepala Desa di Desa Munung Kecamatan Jatikalen Kabupaten Nganjuk. Jurnal Kajian Moral dan Kewarganegaraan, 3(4), hlm. 1855-1869

Solihah, R. (2016). Politik Transaksional dalam Pilkada Serentak dan Implikasinya bagi Pemerintahan Daerah di Indonesia. Jurnal The Politics, 2(1), hlm. 97-109.

Suprianto, L.O., Arsyad, $M$ dan Tawulo, M.A. (2016). Persepsi Masyarakat terhadap Politik Uang pada Pilkada Serentak (Studi Di Desa Ronta Kecamatan Bonegunu Kabupaten Buton Utara). Jurnal Neo Societal, 2(1), hlm. 1-10.

Undang-Undang Republik Indonesia Nomor 3 tahun 1999 tentang Partai Politik 